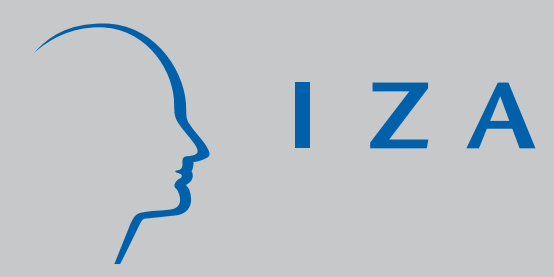

IZA DP No. 953

The Impact of a Primary School Reform on Educational Stratification: A Norwegian Study of Neighbour and School Mate Correlations

Oddbjørn Raaum

Kjell G. Salvanes

Erik Ø. Sørensen

December 2003 


\title{
The Impact of a Primary School Reform on Educational Stratification: A Norwegian Study of Neighbour and School Mate Correlations
}

\author{
Oddbjørn Raaum \\ Ragnar Frisch Centre for Economic Research \\ Kjell G. Salvanes \\ Norwegian School of Economics and Business Administration \\ and IZA Bonn \\ Erik Ø. Sørensen \\ Norwegian School of Economics and Business Administration
}

\author{
Discussion Paper No. 953 \\ December 2003
}

\author{
IZA \\ P.O. Box 7240 \\ D-53072 Bonn \\ Germany \\ Tel.: +49-228-3894-0 \\ Fax: +49-228-3894-210 \\ Email: iza@iza.org
}

This Discussion Paper is issued within the framework of IZA's research area The Future of Labor. Any opinions expressed here are those of the author(s) and not those of the institute. Research disseminated by IZA may include views on policy, but the institute itself takes no institutional policy positions.

The Institute for the Study of Labor (IZA) in Bonn is a local and virtual international research center and a place of communication between science, politics and business. IZA is an independent, nonprofit limited liability company (Gesellschaft mit beschränkter Haftung) supported by Deutsche Post World Net. The center is associated with the University of Bonn and offers a stimulating research environment through its research networks, research support, and visitors and doctoral programs. IZA engages in (i) original and internationally competitive research in all fields of labor economics, (ii) development of policy concepts, and (iii) dissemination of research results and concepts to the interested public. The current research program deals with (1) mobility and flexibility of labor, (2) internationalization of labor markets, (3) welfare state and labor market, (4) labor markets in transition countries, (5) the future of labor, (6) evaluation of labor market policies and projects and (7) general labor economics.

IZA Discussion Papers often represent preliminary work and are circulated to encourage discussion. Citation of such a paper should account for its provisional character. A revised version may be available on the IZA website (www.iza.org) or directly from the author. 
IZA Discussion Paper No. 953

December 2003

\section{ABSTRACT \\ The Impact of a Primary School Reform on Educational Stratification: A Norwegian Study of Neighbour and School Mate Correlations}

School quality is hard to define and measure. It is influenced by not only school expenditures, but also characteristics that are hard to measure like norms and peer effects among teachers and pupils. Furthermore, family background and community characteristics are important in explaining educational outcomes. In this paper we study the composite effect of primary schools and neighbourhoods on adult educational attainment controlling for family characteristics. Instead of identifying the effect of specific neighbourhood and school characteristics on educational attainment, we focus on correlations in final years of schooling among neighbouring children and school mates. We find a clear trend of declining influence of childhood location over the 24 year period (birth cohorts 1947-1970). Then we ask whether a change in the compulsory school law extending the mandatory years of education, can explain this pattern. We find some effect of the primary school reform on the change in the neighbourhood effect. Motivated by the fact that neighbouring children typically go to the same school, we estimate school mate correlations for children born in the 1960s. The overall impact of factors shared by children who graduated from the same school at the age of $15 / 16$ is negligible. The variation in "school quality" and the impact of peers on final educational attainment seem to have been very limited in Norway.

JEL Classification: I21, J13, R23

Keywords: families, neighbours, schools, educational reforms, peer-effects

Corresponding author:

Kjell G. Salvanes

Department of Economics

Norwegian School of Economics and Business Administration

Helleveien 30

5045 Bergen

Norway

Email:kjell.salvanes@nhh.no 


\section{Introduction $^{1}$}

There is a controversy both among researchers and among the public on whether school quality matters, how (much) it matters, why it matters, and for which outcomes it matters. Empirical results from many countries have shown that school resources only have a modest impact on student achievement, but relatively stronger impact on adult educational attainment. ${ }^{2}$ School quality is hard to define and measure. It is influenced by not only school expenditures, but also characteristics that are hard to measure like norms, attitudes and peer effects among teachers and pupils (Hoxby, 2000). Furthermore, family background is important, and it has become clear that community characteristics - peer effects and neighbourhood institutions - are important in explaining educational attainment and adult earnings (Solon, et al. 2001, Page and Solon, 2000, Raaum, Salvanes and Sørensen, 2001).

However, few studies focus on the fact the primary/lower secondary school constitutes an important factor shared by children growing up in the same neighbourhood. The three factors, the family, neighbourhoods (both as peer influence and institutions), and schools, probably also interact strongly as inputs in the human capital production function. Therefore, the causal effects of the three factors are hard to disentangle, partly because of family sorting into neighbourhoods and schools. In the present paper we try to analyse the composite effect of primary schools and neighbourhoods, and attempt to evaluate the two effects on adult educational attainment. Instead of identifying the effect of specific neighbourhood and school characteristics on educational attainment, we focus on correlations in final years of schooling among neighbouring children and school mates.

The starting point for our analysis is twofold. First, in a previous study we found that the importance of family background was stable while the effect of neighbourhoods on educational attainment and earnings is significantly lower for the 1955-65 birth cohort compared to individuals born 1945-55 (Raaum, Salvanes and Sørensen, 2001). Second, in the 1960s - which is the childhood period which the neighbourhood effect was found to be weakened - a primary school reform took place

\footnotetext{
${ }^{1}$ We thank Peter Fredriksson, a referee and the editor of the Swedish Economic Policy Review for valuable comments and suggestions.

${ }^{2}$ School inputs measured by e.g. expenditures, teacher-pupil ratios appear to have modest if any effect on student achievement such as marks and test scores (See Hanushek, 2003, Krueger, 2003 for US results, and for Norway see Bonesrønning, 2003). However, the same type of school resources seem to have a stronger impact on post-school outcomes like final educational attainment and earnings, although these findings are controversial (Betts, 1996, Dearden, Ferri and Meghir, 2002, Dustmann, Rajan and Van Soest, 2003).
} 
in Norway extending the mandatory level of schooling from seven to nine years. Prereform, the Norwegian school system required children to attend school from the age of seven to the age of fourteen. After the reform, this was extended to the age of sixteen by adding two more years of mandatory education. The reform took place over a twelve year period with different municipalities adopting the new school system at different times allowing for time variation as well as regional variation. Evidence in Aakvik, Salvanes and Vaage (2003) suggests that this reform increased the participation in above mandatory education as well as increasing the returns to education. ${ }^{3}$ They also found that the importance of family income was slightly weakened for the post reform students as compared to the pre-reform students.

Our approach in this paper is to use a unique data set for Norway on neighbourhoods, schools and parental background to analyse whether the school reform also had an impact of the equalizing the opportunity across neighbourhoods. ${ }^{4}$ In addition to have aims such as increasing the minimum level of education, and to smooth the transition to higher education, an important aim was also to increase equality of opportunity along socio-economic and geographic dimensions. It is this latter aspect we analyze in this paper. The question is whether the school reform reduced the importance of the local neighbourhood. This type of primary school reform took place in about the same time in many other European countries and we think that Norway is a good case for analyzing social returns of primary educational reforms since the potential impact is expected to be stronger and thus easier to measure in the case of Norway. It has been pointed out that the Norwegian reform along with the Swedish reform went further both in the unification of the comprehensive school system as well as in promoting equality of opportunities (Leschinsky and Mayer, 1990). We then analyse the effect of schools as a part of neighbourhood effects by estimating school mate correlations over time, both as unadjusted correlations and controlled for family sorting. A school mate correlation is an overall measure of neighbourhood and different types of school effects including school resource and peer effect. Again the question is whether school mate correlations have been reduced over time.

\footnotetext{
${ }^{3}$ See Meghir and Palme (2003) an analysis of the similar Swedish reform that took place in the 1950s. They also find that the reform had an impact on participation rates in higher education as well as well as reducing the impact of family background.

${ }^{4}$ See Oreopoulos (2003), Locher and Moretti (2001) and Pischke (2003) for other examples of analyzing social returns as opposed to private returns of educational reforms.
} 
The rest of the paper is organized as follows. In Section 2 we describe our approach, in Section 3 the data set, variable definitions and the educational reform are described. Section 4 provided the empirical results and in the last section we provide some concluding remarks.

\section{Neighbour and School Mate Correlations}

In order to study the impact of schools on adult educational attainment as measured by years of education, and to disentangle the family effects and neighbourhood effects, we use a variance decomposition approach. The idea is simple. If childhood neighbourhoods, have long-lasting effects on welfare, resemblance in adult outcomes will appear among persons who grew up in the same local community. The same line of reasoning applies to schools and children who graduated from the same institution. Our empirical neighbour (school mate) correlation is an estimate of the proportion of the variance in years of schooling explained by factors that neighbouring children (school mates) shared.

In order to illustrate the variance decomposition approach, we use a simple framework suggested by Solon et al. (2000). Let $y_{c f i}$ be the years of education, for sibling $i$ in family $f$ in neighbourhood $c$,

$$
y_{c f i}=\beta^{\prime} Z_{c}+\alpha^{\prime} X_{f c}+\varepsilon_{c f i}
$$

where $X_{f c}$ is a vector of all family characteristics that influence years of education, $Z_{c}$ contains all the neighbourhood characteristics, and $\varepsilon_{c f i}$ represent unrelated individual factors orthogonal to both family and neighbourhood effects. ${ }^{5}$ The total variance in years of schooling can be decomposed as:

$$
\operatorname{var}\left(y_{c f i}\right)=\operatorname{var}\left(\beta^{\prime} Z_{c}\right)+\operatorname{var}\left(\alpha^{\prime} X_{f c}\right)+2 \operatorname{cov}\left(\beta^{\prime} Z_{c}, \alpha^{\prime} X_{f c}\right)+\operatorname{var}\left(\varepsilon_{c f i}\right)
$$

We are looking for the relative influence of neighbourhoods on schooling, i.e. $\operatorname{var}\left(\beta^{\prime} Z_{c}\right) / \operatorname{var}\left(y_{c f i}\right)$. Empirically, we use the observed covariance in educational attainment among neighbouring children from different families. This covariance, using (1), is given by

$$
\operatorname{cov}\left(y_{c f i}, y_{c f^{\prime} i^{\prime}}\right)=\operatorname{var}\left(\beta^{\prime} Z_{c}\right)+\operatorname{cov}\left(\alpha^{\prime} X_{f c}, \alpha^{\prime} X_{f^{\prime} c}\right)+2 \operatorname{cov}\left(\beta^{\prime} Z_{c}, \alpha^{\prime} X_{f c}\right)
$$

As illustrated in (3), the neighbour covariance contains more than the variance of neighbourhood effects. The second term represents clustering of similar families in

\footnotetext{
${ }^{5}$ Since $\mathrm{X}$ and $\mathrm{Z}$ are latent vectors that include all relevant variables, the residual is orthogonal to both.
} 
neighbourhoods. As families typically sort themselves into neighbourhoods, resemblance in outcomes of children growing up in the same local community (or school) will also reflect similar family background. The third term reflects the extent to which families are non-randomly distributed across neighbourhoods. We expect that advantaged families sort into advantaged neighbourhoods, reinforcing the impact of non-random distribution of families on observed neighbour correlation. In the case of school mate correlations, compensating resource allocation across schools will tend to reduce - and possibly even reverse - the positive association between family and school effects.

Empirically, we can estimate the part of $\alpha^{\prime} X_{f c}$ related to observed family characteristics, and adjust the correlation, $\operatorname{cov}\left(y_{c f i}, y_{c f^{\prime} i^{\prime}}\right) / \operatorname{var}\left(y_{c f i}\right)$, by substracting the covariance in predicted family effects (devided by the variance). However, since we control only for observed family characteristics, our estimated neighbour correlation represents an upper bound on the neighbourhood effects, (see Altonji, 1988, Solon et al., 2000, and Page and Solon, 2000). ${ }^{6}$ Obviously, the correlation in adult outcomes among persons who spent their childhood in the same local community, cannot tell why neighbourhoods matter. It includes the joint effects of the distribution of characteristics (Z's) and their causal effects $(\beta$ 's).

'Neighbourhood effects' is a label for a variety of different mechanisms. The attitudes and behaviour of peers, the existence and enforcement of social norms as well as local institutions vary across neighbourhoods. Our focus in on the role of the primary school ${ }^{7}$ as a potentially important factor which neighbouring children share. Disentangling the impact of schools from other neighbourhood characteristics is hard as we don't have any reliable information (or assumptions) on the sorting of neighbours across schools, e.g. why neighbouring children go to different schools.

Our approach is less ambitious. First, we estimate the trend in neighbour correlations over a 25 year period, i.e. birth cohorts 1947-1970, with and without family background adjustment. As a by-product, we report estimates of the trend in intergenerational educational mobility. Second, we focus on specific birth cohorts,

\footnotetext{
${ }^{6}$ Variance decomposition to obtain the upper bound of effect of observed and unobserved effects may be preferred to regression analysis where studies often report unstable and small effects of community characteristics when these are included directly into the estimation equations of adult earnings or educational attainment (for an overview see Ginther, Haveman and Wolfe, 2000).

${ }^{7}$ By primary school we mean institutions responsible for compulsory schooling. It includes what is frequently called (lower) secondary levels.
} 
1947-1956, that were partly affected the primary school reform during the 1960s. We exploit this by estimating neighbour correlations in adult educational attainment by birth cohort for individuals living in municipalities with and without the school reform. The idea is to assess whether the declining impact of neighbourhoods in educational attainment can be attributed to the introduction of the new school system. Finally, we look at school effects by means of school mate correlations. Resemblance in educational attainment among children graduating from the same primary school will reflect the total contribution of school characteristics, including resources and composition of pupils. As similar families tend to cluster in schools, parental background adjustment is needed to tighten the upper bound on school effects. On the other hand, it is not so obvious that disadvantaged families sort into disadvantaged schools as the allocation of school resources tends to favour schools with children in need of special treatment. Unfortunately, data on primary school attendance are not available for children born before 1960 .

\section{Data and school institutions}

\subsection{Families, neighbourhoods and school mates}

The data set has been put together with sources provided by Statistics Norway (Møen, Salvanes, and Sørensen, 2003). The data include linked administrative data covering most of the Norwegian residents. We also have national censuses of 1960 and 1970 (Vassenden 1987). We can link records from these data sets using a unique personal identifier given to all Norwegian residents by the national population register. We use a set of household and census tract identifiers in the census to identify families and place of residence during childhood. For the 1959--1970 birth cohorts we have linked in which primary school they graduated from. The censuses also contain family background variables such as parents' education. The administrative register contains information on adult taxable income (excluding capital gains) and educational attainment. The linking about of administrative to census data is not perfect, but for the subset of individuals we consider in this paper, more than $90 \%$ can be linked across these datasets for the older cohorts, while the degree of linking is close to a $100 \%$ for younger non-immigrants. The main reason for non-linking is that the central register of residents based its first records on the census of 1960, and among those who left home before 1960, little was done to refine information on parents. We have 
to drop some additional individuals with incomplete information on residence. Vassenden (1987) documents the construction and linking of the census files, while Statistics Norway (2001) documents the central register of education.

Neighbourhood is defined as census tract in 1960 or 1970. The total number of tracts increased from 7996 in 1960 to 8818 in 1970, with most of the increase in urban areas. The average tract populations were 464 and 439 respectively, these tracts were considerably smaller than those of most other country censuses of the time (Langen, 1975). With the single-year cohorts we use, the average number of individuals ('neighbours') per neighbourhood that we have information on varies from 6.1 to 8.4, with median neighbourhoods of 4 and 5 individuals.

School mates are individuals who graduated from the same school, leaving compulsory education (age 15/16 typically). The schools are larger than the neighbourhoods, with average cohorts of 62 students (median 49) in the 1959 cohort, with a trend toward smaller schools, the latest cohort for which we have a full year, 1969, the mean graduating class has 55 students (median 41). ${ }^{8}$

We observe the neighbourhood children live in at one point in time. Because families move, the neighbourhood at a single point in time may not accurately represent the environment children grew up in. On the other hand, people may move between very similar neighbourhoods. In a previous paper (Raaum, Salvanes and Sørensen 2001) we examined the differential outcomes among those who stayed and those who changed location between the 1960 and 1970 census (using the list of comparable tract aggregations provided by Langen (1975)). We found there that with respect to neighbour-correlations in adult educational achievement, this factor does not seem to cause major biases.

There are 451 municipalities in the 1970 census, and most of these have at least one school each, only a few have joint schools with neighbouring municipalities. In 1974, 247 municipalities had only one school, but there are 827 schools in all, for an overall average of 1.96 schools per municipality. Mostly, a school district contains a number of census tracts, and by regulation a census tract should not cross school district boundaries although this policy was more strictly enforced in rural than urban areas (Byfuglien and Langen

\footnotetext{
${ }^{8}$ The 1970 cohort is truncated since we have no information on people born after the date of the census (November 1. 1970).
} 
1983). Since some time passes between the census of 1970 and our observations of graduations, which appear from 1974 and onwards, internal migration makes it difficult to examine the map from census tracts to school districts in great detail. Noise induced by migration is correlated with the size of the school district, but the median school district had, as of 1974, graduates from 15 census tracts, whereas the 25th percentile school district had graduates from 11 tracts and the 75 th percentile had 23 tracts represented.

Our measure of adult educational attainment in our main sample is taken from the register of the level of education maintained by Statistics Norway (Statistics Norway, 2001). This register provides a detailed code of the highest completed education, the completion date and how many years of schooling the highest completed education corresponds to. For individuals with no recent education, their level of education as of the 1970 census is recorded.

Information on the educational attainment of parents is different. The census data on parents contain only categorical coding of types of education. We have transformed the categorical education codes into years of education, using a two-step procedure. A first step maps 1960 census codes to 1970 census codes using repeated observations of the same individuals in the two censuses. A second step maps 1970 codes into years of schooling using the oldest observations in the central register of education. See Raaum, Salvanes and Sørensen (2001) for the details of this procedure.

\subsection{The Norwegian mandatory school reform in the 1960s}

In 1959, the Norwegian Parliament passed a law on mandatory schooling and the new compulsory 9 years of schooling was gradually implemented across the country over the years 1960 to 1972. This school reform extended the number of compulsory years of schooling from 7 to 9, keeping school-starting age constant at 7 . It also unified the education system beyond the age of 15/16. Before the reform, two years of junior high school preparing for senior high school was possible to attain in some municipalities, but pupils in other areas had to move to another municipality to attend postcompulsory schools. The nine years in the new system were divided into two levels; first six years of primary school, then three years of lower secondary school which prepared for high school. Hence, for more than a decade the Norwegian compulsory school was divided into two separate systems. The first cohort that was involved in 
the reform was the one born in 1947and the last cohort who went through the old system was born in 1959 .

The aims of the reform, explicitly stated in several governmental papers, were to increase the minimum level of educational attainment by extending the number of compulsory education, to smooth the transition to higher education, and finally to enhance equality of opportunities both along the socio-economic and geographical dimension.

\section{Implementation process of the reform}

Under the law of 1959 for mandatory schooling, each municipality was invited to apply to a committee under the Ministry of Education to implement the reformed school system for the whole municipality. This application should include a plan for the new school in terms of buildings and funding, although the extra costs of teachers and buildings was provided by the state. It is not exactly clear what the criteria were for being selected by the committee among applicants. However, the committee wanted to cover different types of communities making the sample of implementing municipalities representative for the country and also that the plans for buildings, teaching resources etc were acceptable (Telhaug, 1969, Mediås, 2000).

We are assessing changes in neighbourhood effects (a relative measure) and not assessing levels of education, we are less vulnerable to the problem of whether reform adoption was random in terms of school participation above mandatory years of education. However, the question is of course also in our case of interest whether municipalities that have implemented the new system, at any given time (or for any given birth cohort), do not vary systematically from those who still kept the old school with 7 years of compulsory schooling. When comparing municipalities by reform status, systematic unobserved heterogeneity may bias our results. For instance, did the richest municipalities to implement the reform first? Was it the cities? Or was it the other way around that it was poor rural areas who wanted to implement the reform first since there were obvious economic incentives also to implement the reform? In the public debate from the 1950s and 1960s it was claimed that the old educational system with more streaming, prepared better for the high school and university studies than the new system, indicating that perhaps the rich and city areas implemented the reform late. It was also claimed in the public debate at the time that 
9 years of mandatory schooling was not necessary in many rural communities since fishing and farming were the main industries and those did not require 9 years or higher education.

We are not checking these hypotheses carefully in this paper, only presenting some indication of a possible relationship between the average years of parental schooling, by birth cohort of their child and reform status displayed in Figure 1. The figure suggests that the unconditional transition (probability) was positively correlated with the educational attainment of the parents. In Aakvik, Salvanes and Vaage (2003), a detailed analysis of the process of allocating the reforms to municipalities is undertaken. As indicated from Figure 1, the case is not completely clear, but a more detailed analysis did not find support for systematic allocation of the reform to municipalities.

\section{Identification of reform status}

Information on what type of primary school people attended is only available for those who never continued schooling above the mandatory years, so it is necessary to classify the type of primary education based on municipality of residence in the censuses of 1960 and 1970. It is, however, not an easy task to find municipality level information on reform implementation. The most authoritative list is Ness (1971), but this list is organized by 1970 municipality. A series of municipality mergers and boundary adjustments throughout the 1960s make it difficult to fix a point in time for the reform based on 1960 municipality. We want to concentrate on finding a date of implementation using the 1960 municipalities; since a 1970 municipality can include several 1960 municipalities with different dates of implementation, and thus it is more difficult to fix a unique implementation year for the 1970 municipalities.

We use a classification scheme based on administrative data on adult educational achievement, focusing on those who left school with only primary education, let us call these people the "dropouts". For each 1960 municipality, we follow the cohorts of those who lived there at the time of the 1960 census. For each year we can calculate the share of dropouts from the old system and the share of dropouts from the new system. We want to use these dropout rates to calculate two candidate measures of reform date: The first one when the dropouts from the old 
system stop appearing, and the second one when the dropouts from the new system start showing up.

Since we must allow for some migration, we cannot simply use indicators of whether there are any dropouts at all as measures of school type. Such a scheme would be much too sensitive to internal migration of even a single individual who moved and dropped out in a municipality with a different implementation date than the one he left. This problem would be particularly important for dating reform in the larger municipalities since they receive the many migrants. In order to get around this we need to measure the number of dropouts relative to the population of potential dropouts, and we need to set a positive cut-off rate to allow for some measurement error. We also want to avoid that this measurement error is systematically related to the schooling pattern in the municipalities, so we cannot use a uniform cut-off rate across all municipalities. Instead we calculate municipality specific "normal rates" of dropout based on the dropout rates of the 1946--48 cohorts who were not exposed to the reform. When the dropout rate from the old system falls below 50 per cent of this "normal" rate, we have the first candidate date of when the reform was implemented. Similarly, we calculate such normal dropout rates from the new system using the 1957--59 cohorts who we know with certainty went through the new system. The year the rate of dropouts from the new system reach 50 per cent of this second normal rate is our second candidate date of reform implementation.

When the two candidate measures agree on what year the reform was implemented, we use this as the year of implementation. Should there be a gap of one or two year between the two candidate measures, such that it would seem that the old system closed before the new one opened, we use the second candidate measure since this is most resistant to a secular decrease in the dropout rate. Should there instead be an overlap of one year between the two candidate measures, such that it seems the old system and the new system coexisted for a year, we tried to check all larger municipalities (with more than 100 students) against the list in Ness (1971) and local informants. For smaller municipalities with one-year overlaps, we have randomly assigned one of the candidate years. The remaining municipalities, for which none of these methods worked, have been dropped from the sample. While there will certainly be some measurement error in our reform date taken as a flow indicator of reforms, we believe the measurement error in the stock of reformed and non-reformed municipalities for a given year is small. 
This method provides a year of implementation for 545 out of 728 municipalities. Table 1 displays the relative importance of the various rules in assigning an implementation date. The slow and gradual implementation for the reform is illustrated in Figure 2. Table A4 in the Appendix presents descriptive statistics for the included and non-included neighourhoods. As we can see there is very little difference. In our analysis below, we only consider birth cohorts where the smallest of the reformed and the non-reformed group constitutes at least 5 per cent of the students, and we therefore exclude the 1946--47 and the 1957--59 cohorts.

\section{Results}

Neighbour and school-mate correlations are estimated using the full list of all unique pairs within neighbourhoods or schools that are not also siblings, see Solon et al (2000). Correlations are reported separately for each birth year, in order to distinguish between neighbourhoods located in pre- and post-reform municipalities. If we expanded the number of birth cohorts, each neighbourhood would consist of children who went to different school systems. One might argue that children are affected by the attitudes and behaviour among older peers and not only by those of equal age. However, those born in the same year would be exposed to the same environment, e.g. have the same older role models. Detailed results are reported in Appendix Tables A1-A3.

\subsection{Trend in the effects of childhood neighbourhood and parental education}

Figure 3 displays the correlations in educational attainment among neighbouring children by birth cohort. ${ }^{9}$ The neighbourhoods of the 1947--1958 cohorts are defined by the 1960 census, while the 1970 census defines the neighbourhoods for the 1955-1970 cohorts. The figure also includes the family background adjusted correlations which subtracts the covariance component arising from sorting on observed family characteristics (i.e. parental education). The correlations are substantial, around 0.1, for the cohorts born in the late 1940s and early 1950s. There is a clear trend of declining correlations until around the 1962 cohort, but from then onwards, the correlations are basically constant at a level of about 0.025 . Since the estimates using

\footnotetext{
${ }^{9}$ The standard errors are not displayed, but they are very small and vary around 0.006 , see Appendix.
} 
the two alternative neighbourhood definitions for the 'overlapping' birth cohorts, 1955-58, are basically the same, the lower correlations in the 1960 cohorts cannot simply reflect a change in the definition of neighbourhoods.

Apparently, correlations in Figure 3 are small and some may find them negligible. However, if we convert an correlation estimate of 0.1 into 'level effects' in years of schooling, we get a standard deviation of neighbourhood effects which amount to about 0.95 years. $^{10}$ A correlation of 0.03 corresponds to a standard deviation of 0.5 years of schooling. Consequently, even seemingly negligible correlations are non-trivial. For comparison, a correlation of 0.4 , which is the typical number for Norwegian siblings, corresponds to a standard deviation of effects of 1.9 years of schooling.

Figure 3 also reveals that family sorting matters. In order to adjust for parental education we regress educational attainment on schooling years of the father and mother and neighbourhood dummies. Subtracting the covariance of predicted family effects from the total covariance and dividing by the total variance of educational attainment, we get the adjusted neighbour correlations. When correlations are adjusted for parental education, the estimates are reduced by more than fifty percent. While the neighbour correlations for the cohorts in the late 1940s and early 1950s remain significant, at around 0.04, it drops steadily over time and is close to zero from the 1960-cohorts onwards. As even the family adjusted correlations can be seen as upper bounds on the neighbourhood effects, we conclude that the impact of childhood community on adult educational attainment is negligible for Norwegians who are today in their thirties and early forties.

The declining neighbourhood effects may reflect that sorting on unobserved family characteristics have become less severe over time. This explanation can be checked by looking at how adult education is distributed within and between neighbourhoods over time, since we expect the sorting on the basis of parental education to be the same as on unobserved characteristics. Table 2 is taken from Raaum, Salvanes and Sørensen (2001) and shows that the between-neighbourhood component has become more important over time, indicating that sorting has been more, rather than less, severe.

The family adjustment is based on cohort-specific estimates of the association between the schooling years of parents' and children. Figure 4 displays the estimated

\footnotetext{
${ }^{10}$ By rearranging (3) and use of the observed standard deviation in schooling which is about 3.
} 
regression coefficient of the schooling years of the mother and father. An interaction term turn out negative and the coefficients are evaluated at the mean for fathers and mothers. Two striking results appear. First, there is a clear trend of declining association between education attainment of parents and child, suggesting that intergenerational educational mobility has increased, in accordance with Bratberg, Nilsen and Vaage (2002). Second, the 'effect' of mother's education seems to be the stronger.

\subsection{Neighbour correlations by primary school reform status}

For each of the 1948-1956 birth cohorts, we classify individuals as 'before- or afterreform' according to the reform-status of the municipality in which their neighbourhood is located. Neighbour correlations are then estimated separately by cohort and reform status. This exercise is motivated by the pattern of declining neighbour correlations; ff the primary school reform lowered the impact of childhood location, we expect to find a lower correlation among neighbouring children who went to the new school system. Consequently, as more children were entering the new school, the overall neighbour correlation would drop as a result of the reform.

The neighbour correlations are displayed in the left panel in Figure 5, while the family adjusted estimates are shown in the right panel. First, looking at the left panel we see that the after-reform correlations are all lower than the before-reform correlations during the first seven years (incl. the 1953 cohort). By 1953 about 50 per cent of the cohort lived in municipalities which had implemented the new school system. Thereafter, the correlations of two groups are basically the same. We also see that the trend of declining correlations, with exception for the 1953-cohort, remains when we consider the before-reform neighbourhoods. No such trend is found for the after-reform individuals.

Second, the right panel shows that the difference according to reform status drops significantly when we adjust for parental education. Although the estimated neighbour correlations are higher in the before-reform municipalities in seven of nine cases, there is no clear pattern. There is a tendency of lower post-reform correlations in municipalities that implemented early. This is restricted to the 1947-1951 cohorts and the fraction of pupils in the new school is less than 25 per cent in these cohorts. 
At most, the primary school reform implemented throughout the 1960s had a modest impact on the overall trend of declining neighbourhood effects.

\subsection{School mate correlations}

A lower secondary school identifier is available from 1974 onwards, enabling us to construct school mates defined as children born between 1959 and 1970 who graduated from the same school around the age of 15/16. All went to the new system with nine years of compulsory schooling. Figure 6 displays correlations in years of schooling among school mates, by birth cohort. The upper line shows the unadjusted correlations and we recognize the pattern of declining correlations found among neighbouring children of the pre-1962 cohorts. We note, however, that the school mate correlations are significantly lower than the corresponding neighbour correlations.

Again, we expect that the sorting of families into local communities and school areas will give a positive bias in the estimates of overall school effects. The family adjusted school mate correlations are significantly lower and even close to zero. Thus, we find a negligible impact of factors shared by children who graduated from the same school at the age of 15/16. In other words, the variation in 'school quality' and the magnitude of peer-effects seem to be very small. This is consistent with the negligible neighbour correlations of the same cohorts and also the low levels of 'between-school' variance typically found in studies of student performance distributions (Coleman et al., 1966, OECD, 2003). One caveat needs to be emphasized. The interpretation of a family adjusted school mate correlation as an upper bound on the school effects is based on the assumption that children of 'advantaged' families go to 'good schools', i.e. $\operatorname{cov}\left(\beta^{\prime} Z_{c}, \alpha^{\prime} X_{f_{c}}\right) \geq 0$. Since school resources are partly distributed in a compensating way which provides extra resources to schools teaching pupils with specific needs, this assumption may not hold. On the other hand, our family background adjustment is unlikely to account for the total impact of clustering of similar families in schools.

\section{Conclusions}

This paper has studied the composite effect of primary schools and neighbourhoods on adult educational attainment in Norway with particular emphasis of changes over time. We focus on correlations in final years of schooling among neighbouring 
children as well as school mates. These correlations measure the proportion of the variance in years of schooling explained by factors shared by individuals who grew up in the same local community or graduated from the same school at the age 15/16. We do not identify the effects of specific neighbourhood and school characteristics, but the correlations measure the relative importance of childhood neighbourhood and school. As such, the measures are closely linked to 'inequality of opportunity' where the location of your parents' home affects your adult outcome.

The impact of neighbourhoods on educational attainment has diminished, in accordance with Raaum, Salvanes and Sørensen (2001). Estimating neighbourhood effects for all birth cohorts from the late 1947 to 1970, we find a clear trend of declining correlations until around the 1962 cohort. From then onwards, the correlations are basically constant and close to zero when we adjust for family sorting into local communities.

We single out the primary school reform gradually introduced during the 1960 s as a potential explanation, because the primary schools constitute a part of the neighbourhoods. The reform extended the compulsory schooling from 7 to 9 years, provided a common curriculum for all schools and was aimed at equalizing opportunities across socio-economic and geographical backgrounds. For each of the 1947-1956 birth cohorts, we classify individuals as 'before- or after-reform' according to the reform-status of the neighbourhood. The estimated neighbour correlations tend to be higher in the before-reform municipalities, but the difference is reduced when we adjust for parental education. The primary school reform implemented throughout the 1960s cannot fully explain the trend of declining neighbourhood effects in Norway.

Finally, we estimate school mate correlations for children born between 1959 and 1970, looking for the impact of factors shared by children who graduated from the same school at the age 15/16. Effects of school resources and organizational practices, peer effects within schools and local communities are included in this measure. Accounting for family sorting, the school mate correlations are close to zero. Thus, the variation in 'school quality' and the impact of peers on final educational attainment seem to have been very limited in Norway, consistent with the negligible neighbour correlations found for the same cohorts.

Focusing on Norwegians presently in their thirties and early forties, their childhood neighbourhood and primary school have had a negligible impact on their 
educational attainment. Since significant neighbourhood effects are found for those ten years older, it seems likely that policy changes have been effective in leveling the playing field across local communities. Even if the effects of the primary school reform are found to be limited, we believe that redistributive policies equalizing spending across municipalities and other educational reforms are likely explanations.

Family background, however, remains to be an important determinant of educational attainment. The evidence on how family effects have changed over time is mixed. Apparently, the declining association between educational attainment of children and parents, as well the drop in neighbourhood effects, are both at odds with the stable sibling correlations found in Raaum, Salvanes and Sørensen (2001). As neighbourhood and parental education represent factors typically shared by siblings, we would expect sibling correlations to fall as well. However, alternative measures of intergenerational mobility do not necessarily change in the same direction. Sibling correlations are affected by intra-family resemblance as well as inter-family differences. Imagine that educational reforms induce all 'talented' children from 'disadvantaged' families (where 'talent' is shared by siblings), to continue school and enter higher education. If parental resources only allowed one of the children to enter university in the earlier cohorts, the reforms would reduce intra-family differences which would contribute to a higher resemblance in educational attainment among siblings. This example illustrates the possibility that intra-family resemblance is strengthened, while differences between families are reduced.

In the Nordic countries, access to rich administrative and census data has opened up during the last five to ten years. Matched data on individuals, families, schools and neighbourhoods facilitate new approaches in future studies which try to disentangle the effects of these factors. Good data help a lot, but the real challenge is to establish a framework which enables us to identify behaviour as well as responses to policy changes. 


\section{References}

Aakvik, A. Salvanes, K. G. and Vaage, K. (2003). "Measuring the Heterogeneity in the Returns to Education in Norway using Educational Reforms", CEPR DP 4088.

Altonji, J.G. (1988). "The effects of family background and school characteristics on education and labor market outcomes of relatives", mimio, Northwestern University.

Betts, J. R. (1996). “Do school resources matter only for older workers?”, Review of Economics and Statistics, Vol. 78, pp. 638-652.

Bonesrønning, Hans. 2003. "Class Size Effects on Student Achievement: Patterns and Explanations", Southern Economic Journal, forthcoming.

Bratberg, Espen, Øivind Anti Nilsen, and Kjell Vaage. 2002. "Assessing Changes in Intergenerational Earnings Mobility." Centre for Economic Studies in Social Insurance Working Paper No. 54, University of Bergen, December.

Byfuglien, J. and Langen, O. R. (1983). Grunnkretser, tettsteder og menigheter: Dokumentasjon 1980. Statistisk sentralbyrå, rapport 83/13.

Coleman, J. S. et al. (1966). Equality of Educational Opportunity. Washington DC: US GPO.

Dearden, L., Ferri, J. and Meghir, C. (2002)."The effect of school quality on educational attainment and wages", Review of Economics and Statistics, Vol. 84, pp. $1-20$.

Dustmann, C., Rajah, N. and Van Soest, A. (2003). "Class size, Education and Wages", Economic Journal, vol 113, pp. F99-F120.

Falch, T. and Tovmo, P. (2001). "Norwegian local finance in the 1930s and beyond", mimeo, The Norwegian University of Science and Technology. 
Ginther, D., Haveman, R. and Wolfe, B. (2000). "Neighbourhood attributes as determinants of children's outcomes: How robust are the relationships?" Journal of Human Resources, vol. 35, pp. 603-42.

Hanushek, E. (2003). "The Failure of Input-Based Schooling Policies", Economic Journal, vol 113, pp. F64-F98.

Hoxby, C. (2000). "Peer effects in the classroom", NBER working paper No. 7867.

Krueger, A. B. (2003): "Economic Considerations and Class Size" Economic Journal, vol 113, pp. F34-F63.

Langen, O. R. (1975). Folketellingskretsene i Norge i 1960 og 1970: Sammenliknbare kretsenheter.

Leschinsky, A. and Mayer, K. A. (eds.) (1990). The Comprehensive School Experiment Revisited: Evidence from Western Europe. Frankfurt am Main: P. Lang.

Lochner, L. and Moretti, E. (2002). "The effect of education on crime: evidence from prison inmates, arrests, and self-reports”, NBER working paper no. 8986.

Mediås, O. A. (2000). Fra griffel til PC. Steinkjer: Steinkjer kommune.

Meghir, Costas and Marten Palme. 2003. "Ability, parental background and education policy: empirical evidence from a social experiment”, Mimeo, Stockholm School of Economics.

Møen, Jarle, Kjell G. Salvanes and Erik Ø. Sørensen. 2003. "Documentation of the Linked Empoyer-Employee Data Base at the Norwegian School of Economics.” Mimeo, The Norwegian School of Economics and Business Administration.

Ness, E. (red). (1971). Skolens årbok 1971. Oslo: Johan Grundt Tanum Forlag.

OECD (2003). PISA, Literary Skills for the World of Tomororrow, OECD and Unesco, http://www1.oecd.org/publications/e-book/960307. 
Oreopoulos, P. (2003). "The compelling effects of Compulsary schooling: evidence from Canada”, Department of Economics, University of Toronto.

Pischke, J.-S. (2003). "The impact of length of school years on student performance and earnings: evidence from the German short school years", London School of Economics.

Raaum, O., Salvanes, K.G. and Sørensen, E. Ø. (2001). ”The Neighbourhood is not what it used to be" Discussion paper 36/2001, The Norwegian School of Economics.

Page, M.E. and Solon, G. (2003). "Correlations between brothers and neighbouring boys in their adult earnings: The importance of being urban", Journal of Labor Economics, forthcoming.

Solon, G. Page, M.E., and Duncan, G.J. (2000). "Correlations between neighbouring children in their subsequent educational attainment", Review of Economics and Statistics, Vol. 82, pp. 383-392.

Statistics Norway (2001). Utdanningsstatistikk: Dokumentasjon 2000 av den individbaserte utdanningsstatistikken. Norges offisielle statistikk C645, Statistisk sentralbyrå.

Telhaug, A. O. (1969). Den 9-årige skolen og differensieringsproblemet. En oversikt over den historiske utvikling og den aktuelle debatt. Oslo: Lærerstudentenes Forlag. Vassenden, Kåre (1987). Folke- og boligtellingene 1960, 1970 og 1980. Dokumentasjon av de sammenliknbare filene. Statistisk sentralbyrå, rapport 87/2. 


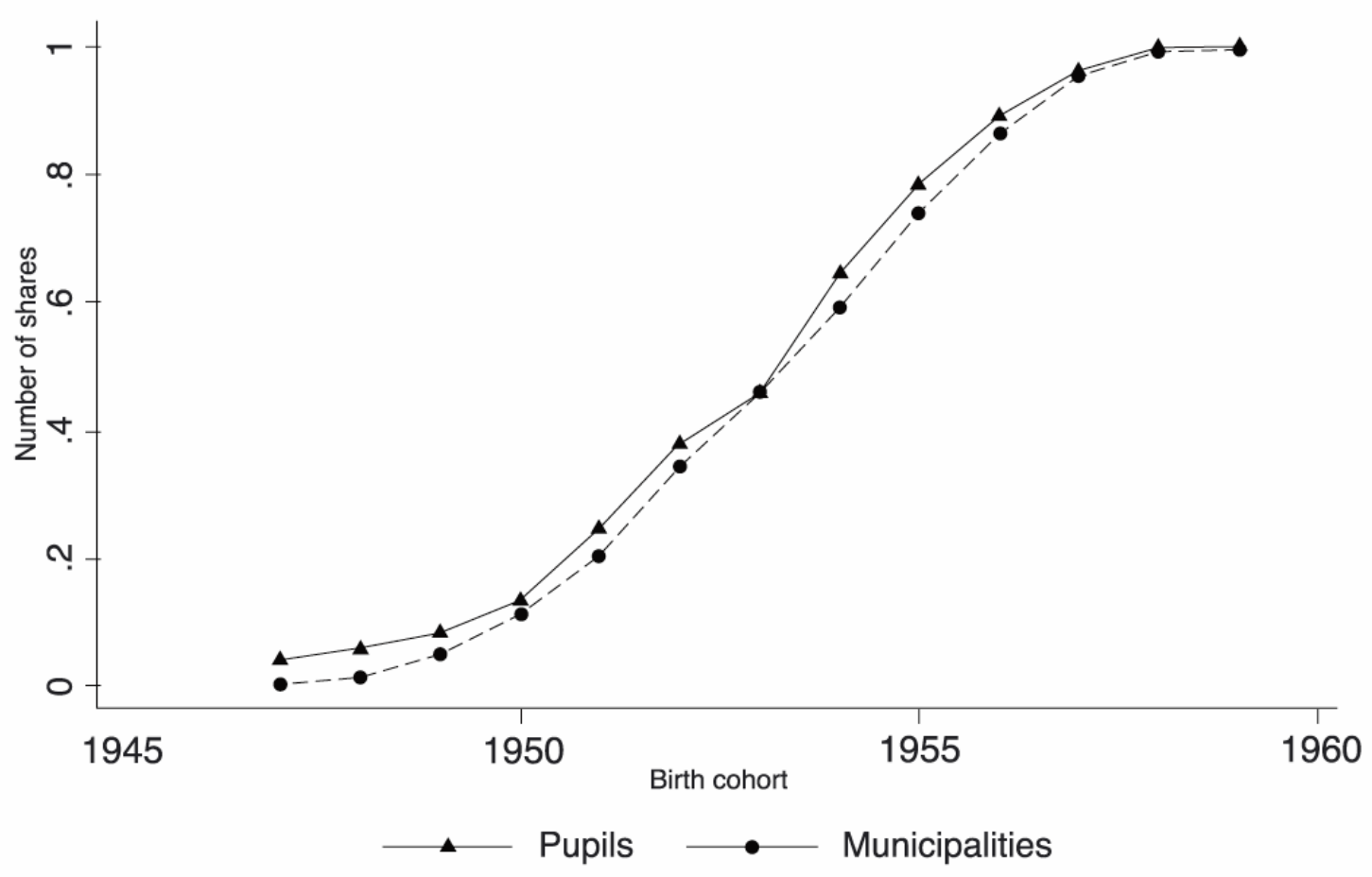

Figure 1. Accumulated shares of after-reform municipalities and pupils.

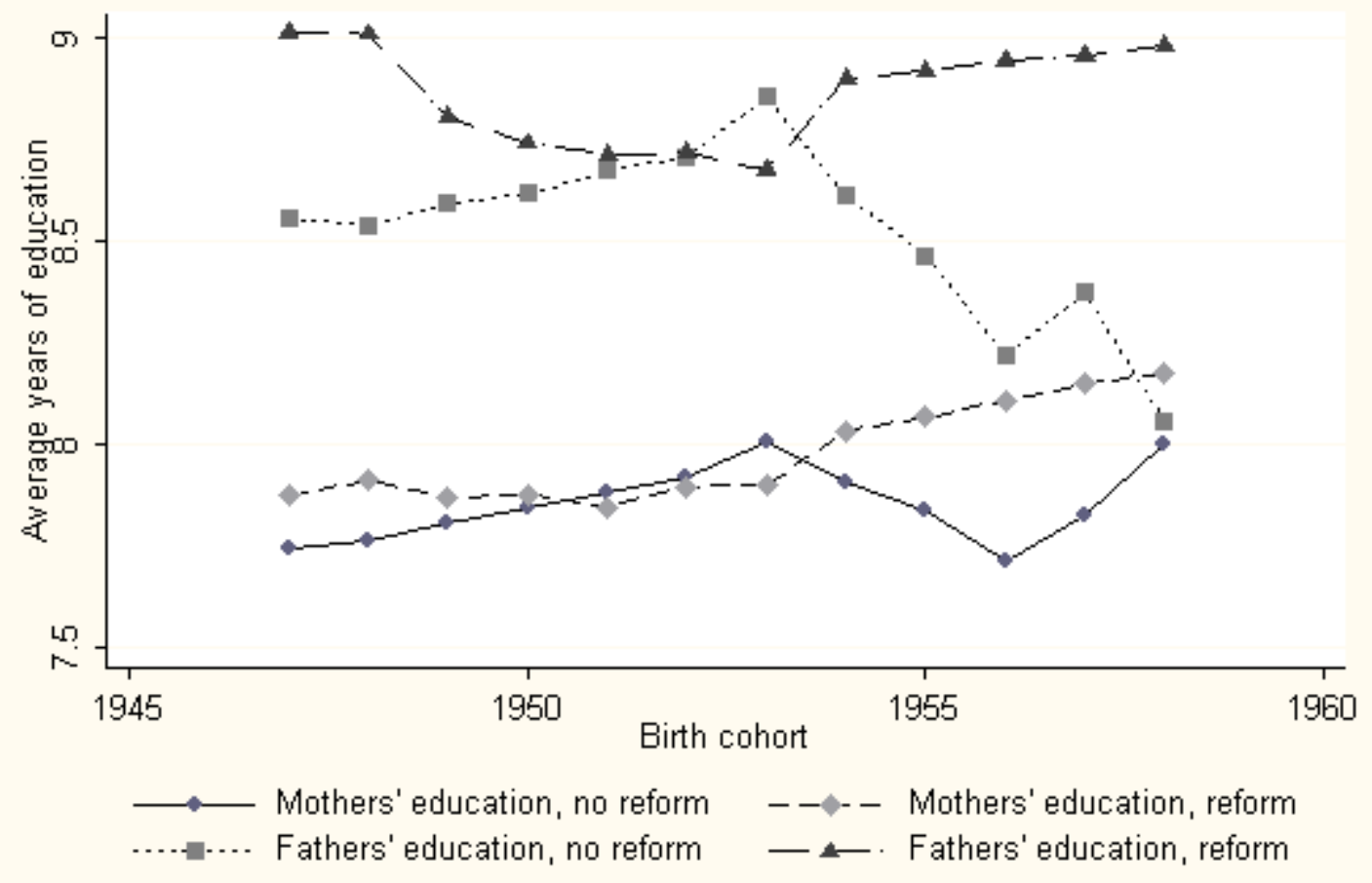

Figure 2. Parental Years of Education. By Primary School Reform Status and Birth Cohort. 


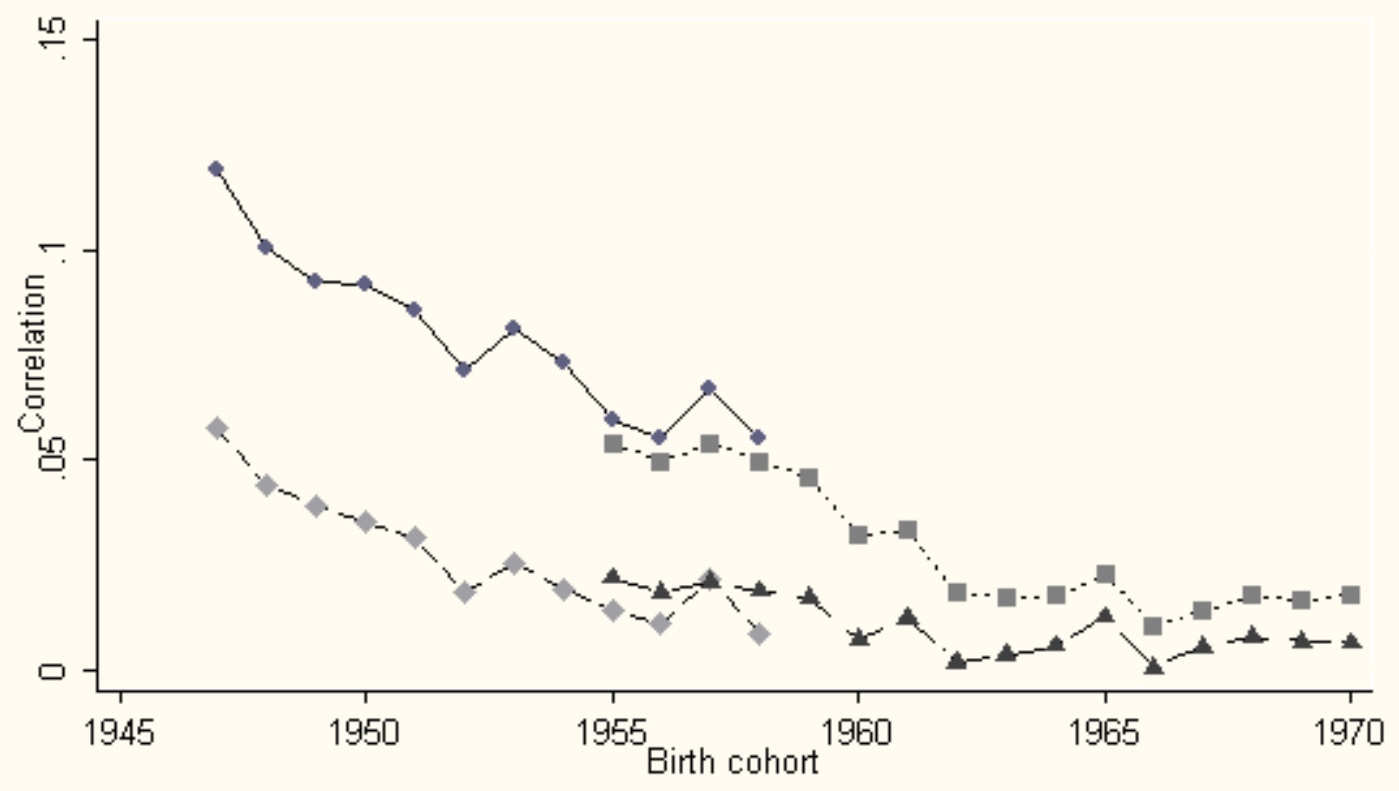

$\longrightarrow$ - Neighbour correlations $1960--\diamond--$ Neighbour correlations 1960, adjusted ......... Neighbour correlations $1970 \_-$Neighbour correlations 1970, adjusted

Figure 3. Neighbour Correlations by Birth Cohort.

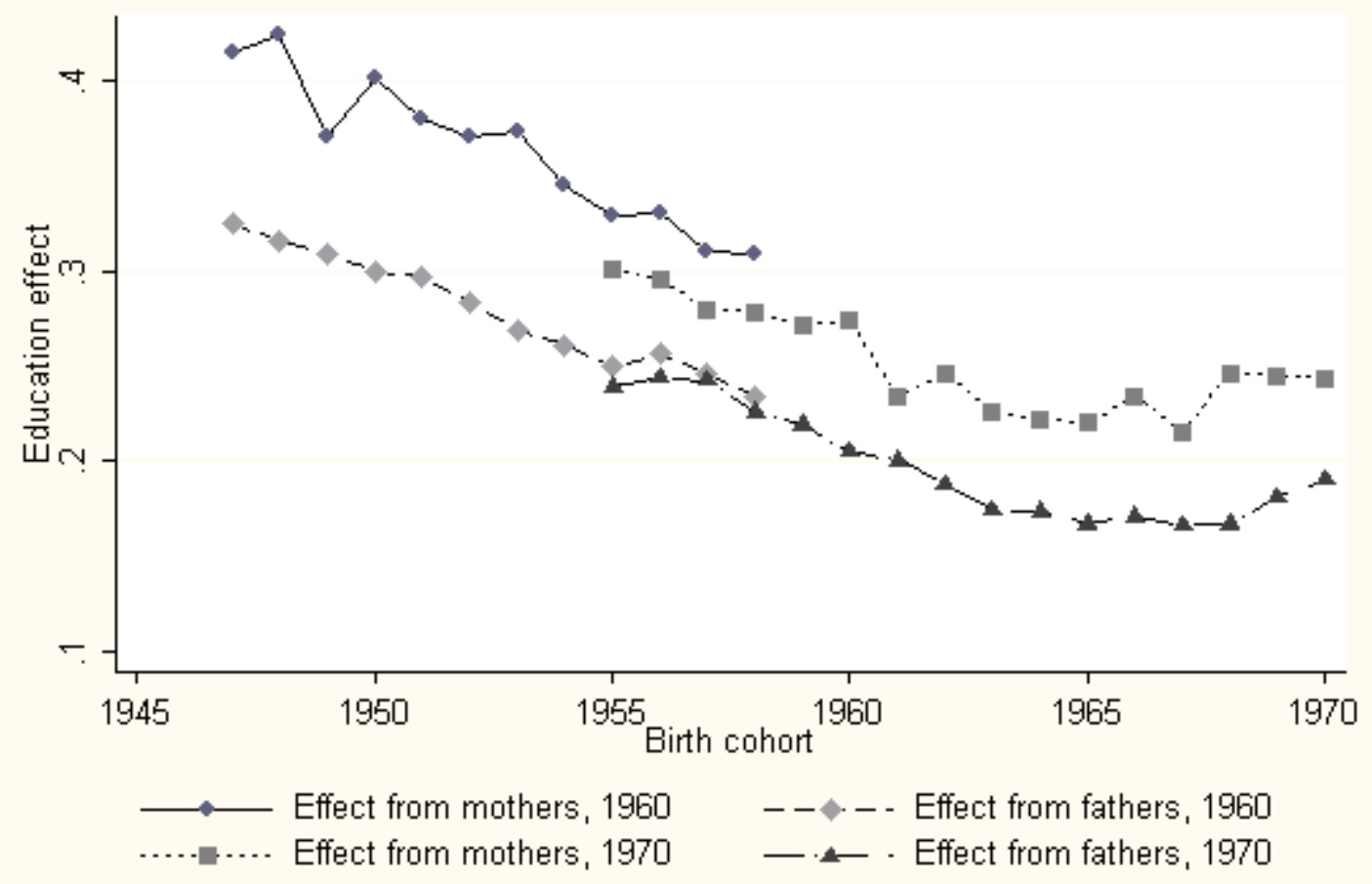

Figure 4. Effects of parental education on children's schooling. By Birth Cohort. 


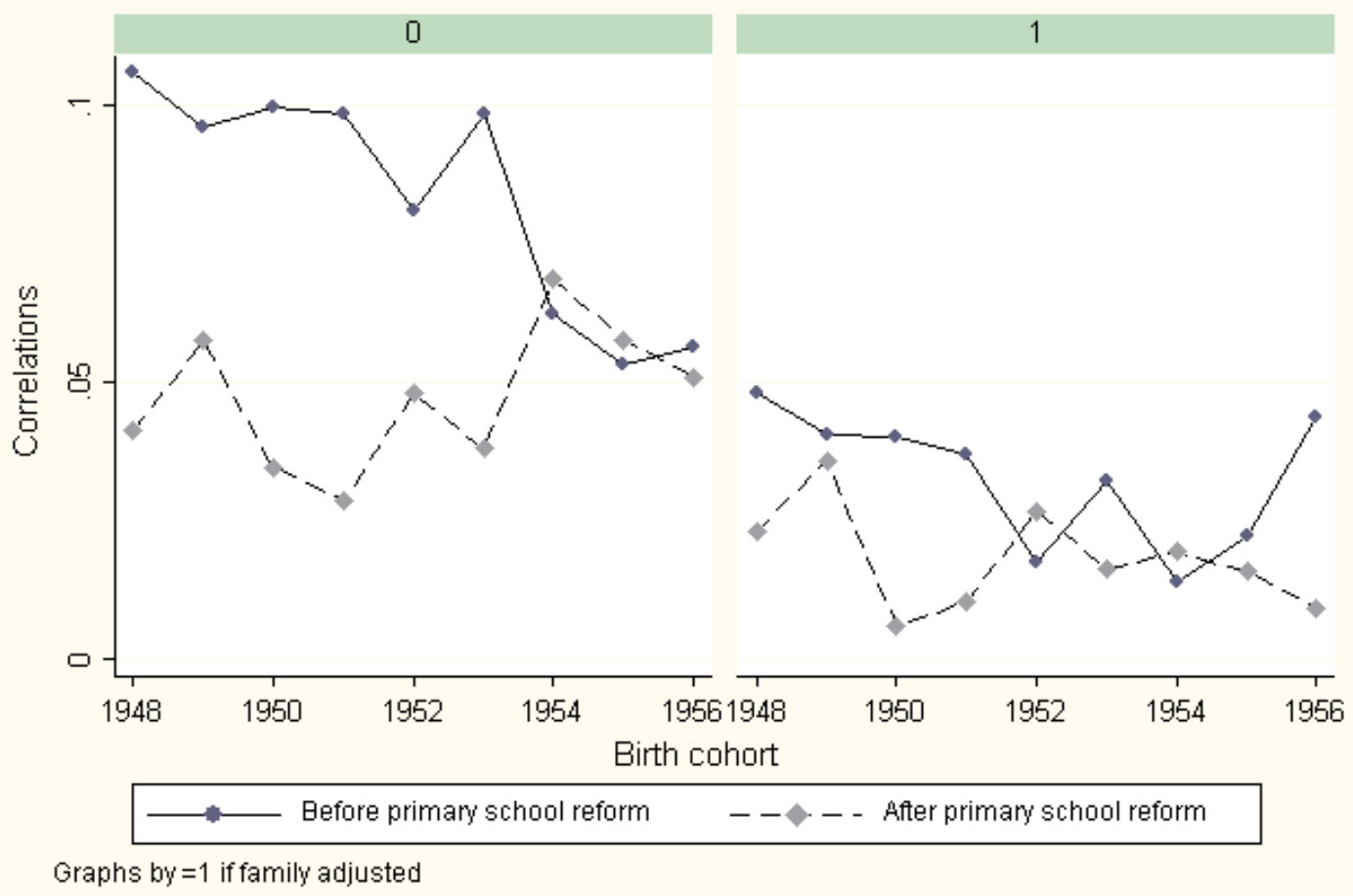

Figure 5. Neighbour Correlations. By Primary School Reform Status and Birth cohort.

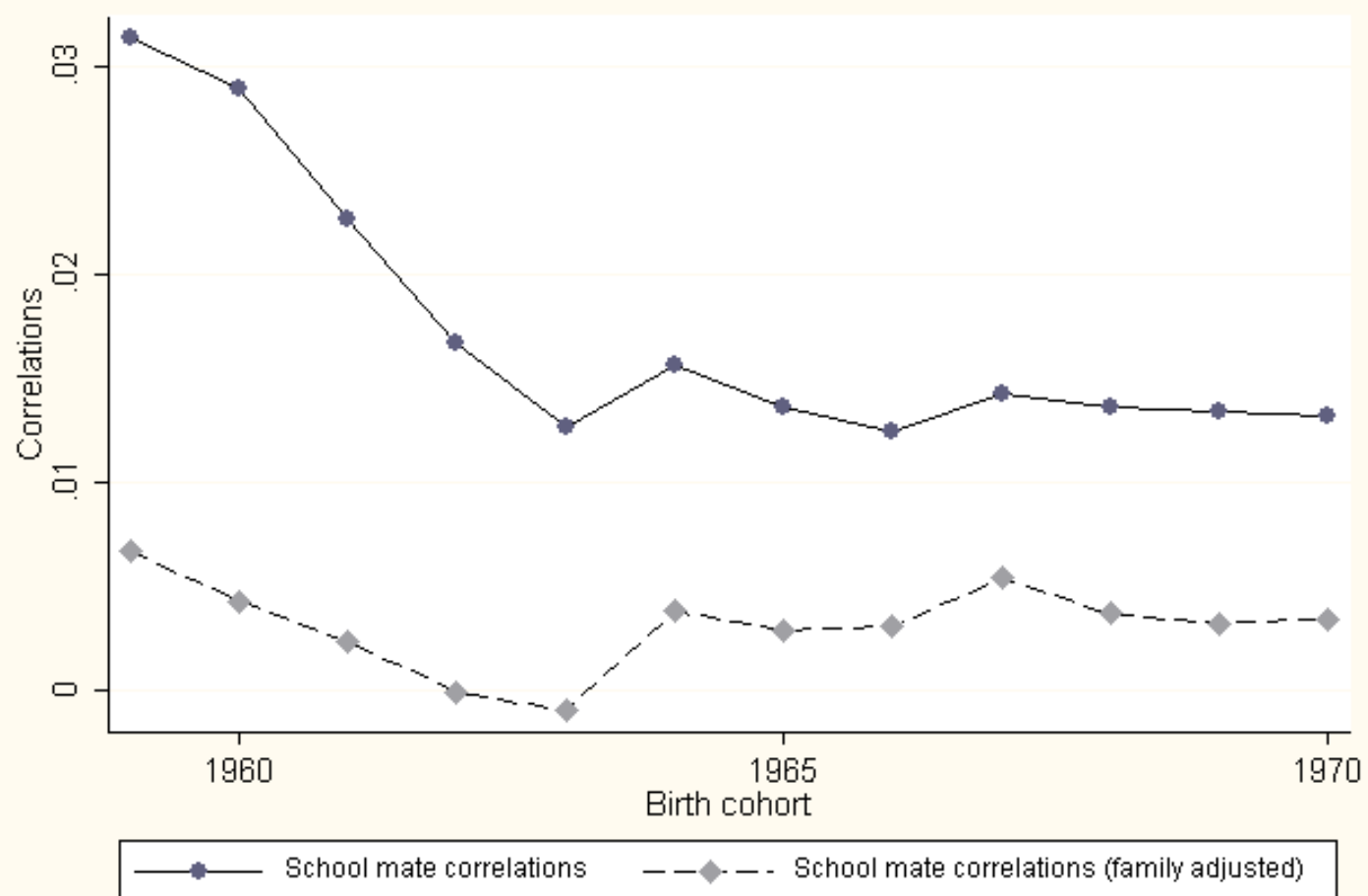

Figure 6. School Mate Correlations. By Birth Cohort. 
Table 1. Procedures of reform year identification

\begin{tabular}{lll}
\hline & Share of municipalities & Share of pupils \\
\hline The two indicators coincide & 0.398 & 0.555 \\
One year gap & 0.143 & 0.125 \\
Two year gap & 0.059 & 0.042 \\
Manual inspection & 0.029 & 0.078 \\
Random assignment & 0.116 & 0.071 \\
Undecided, not used & 0.255 & 0.129 \\
\hline
\end{tabular}

Table 2. Degree of neighbourhood sorting

\begin{tabular}{lllll}
\hline & \multicolumn{2}{c}{ Mother's education } & \multicolumn{2}{c}{ Father's education } \\
\cline { 2 - 5 } & \multicolumn{1}{c}{$1945-55$} & $1955-65$ & $1945-55$ & $1955-65$ \\
\hline mean & 8.005 & 8.678 & 8.771 & 9.503 \\
$\hat{\sigma}_{u}$ & 0.611 & 0.846 & 0.780 & 1.314 \\
$\hat{\sigma}_{e}$ & 1.578 & 1.814 & 1.873 & 2.505 \\
$\hat{\rho}=\hat{\sigma}_{u}^{2} /\left(\hat{\sigma}_{u}^{2}+\hat{\sigma}_{\varepsilon}^{2}\right)$ & 0.130 & 0.179 & 0.171 & 0.216 \\
\hline
\end{tabular}

Note: The decomposition of the variance of parental schooling. Estimates from the fixed effect regression $E_{i c}=\bar{E}+u_{c}+\varepsilon_{i c}$ (neighbourhood fixed effects). Sample is restricted to parents 30-50 at the time of the censuses. This table is taken from Raaum, Salvanes and Raaum (2001). 


\section{Appendix}

The correlation estimator is described in Solon et al (2000). Each neighbourhood or school-mate group consists of many pair of individuals. Earlier research has indicated that weighting strategy is not critical, so all these pairs are weighted equally and an ordinary correlation is calculated on this expanded dataset. For calculation of the standard errors we have used a bootstrap estimator, resampling with municipalities as clustering unit and 300 replications.

Table A1. Trend in Neighbour Correlations

\begin{tabular}{|c|c|c|c|c|}
\hline Birth Cohort & 1960 neighbourl & & 1970 neighbourl & \\
\hline & Unadjusted & Family adjusted & Unadjusted & Family adjusted \\
\hline 1947 & $0.1191(0.0289)$ & $0.0576(0.0106)$ & & \\
\hline 1948 & $0.1004(0.0179)$ & $0.0438(0.0056)$ & & \\
\hline 1949 & $0.0924(0.0144)$ & $0.0392(0.0043)$ & & \\
\hline 1950 & $0.0918(0.0170)$ & $0.0352(0.0043)$ & & \\
\hline 1951 & $0.0853(0.0153)$ & $0.0314(0.0041)$ & & \\
\hline 1952 & $0.0713(0.0109)$ & $0.0187(0.0038)$ & & \\
\hline 1953 & $0.0813(0.0159)$ & $0.0257(0.0043)$ & & \\
\hline 1954 & $0.0732(0.0128)$ & $0.0194(0.0032)$ & & \\
\hline 1955 & $0.0596(0.0084)$ & $0.0140(0.0030)$ & $0.0534(0.0066)$ & $0.0220(0.0042)$ \\
\hline 1956 & $0.0554(0.0068)$ & $0.0112(0.0038)$ & $0.0498(0.0073)$ & $0.0187(0.0033)$ \\
\hline 1957 & $0.0673(0.0096)$ & $0.0215(0.0034)$ & $0.0542(0.0069)$ & $0.0213(0.0039)$ \\
\hline 1958 & $0.0552(0.0063)$ & $0.0089(0.0055)$ & $0.0495(0.0065)$ & $0.0189(0.0037)$ \\
\hline 1959 & & & $0.0460(0.0069)$ & $0.0173(0.0036)$ \\
\hline 1960 & & & $0.0321(0.0059)$ & $0.0074(0.0034)$ \\
\hline 1961 & & & $0.0332(0.0037)$ & $0.0122(0.0036)$ \\
\hline 1962 & & & $0.0185(0.0027)$ & $0.0018(0.0038)$ \\
\hline 1963 & & & $0.0175(0.0030)$ & $0.0036(0.0038)$ \\
\hline 1964 & & & $0.0177(0.0029)$ & $0.0058(0.0035)$ \\
\hline 1965 & & & $0.0229(0.0029)$ & $0.0 .128(0.0034)$ \\
\hline 1966 & & & $0.0106(0.0025)$ & $0.0008(0.0026)$ \\
\hline 1967 & & & $0.0141(0.0025)$ & $0.0055(0.0025)$ \\
\hline 1968 & & & $0.0177(0.0027)$ & $0.0080(0.0025)$ \\
\hline 1969 & & & $0.0166(0.0029)$ & $0.0070(0.0022)$ \\
\hline 1970 & & & $0.0181(0.0042)$ & $0.0066(0.0037)$ \\
\hline
\end{tabular}

Table A2. Neighbour correlations by reform status

\begin{tabular}{|l|l|l|l|l|}
\hline Birth Cohort & \multicolumn{2}{l|}{ Post-reform neighbourhoods } & \multicolumn{2}{l|}{ Pre-reform neighbourhoods } \\
\hline & Unadjusted & Family adjusted & Unadjusted & Family adjusted \\
\hline 1948 & $0.0414(0.0127)$ & $0.0229(0.0101)$ & $0.1059(0.0186)$ & $0.0480(0.0066)$ \\
\hline 1949 & $0.0574(0.0145)$ & $0.0358(0.0147)$ & $0.0959(0.0160)$ & $0.0404(0.0049)$ \\
\hline 1950 & $0.0343(0.0094)$ & $0.0058(0.0098)$ & $0.0100(0.0162)$ & $0.0400(0.0041)$ \\
\hline 1951 & $0.0285(0.0054)$ & $0.0102(0.0063)$ & $0.0985(0.0164)$ & $0.0367(0.0069)$ \\
\hline 1952 & $0.0480(0.0059)$ & $0.0267(0.0055)$ & $0.0812(0.0163)$ & $0.0175(0.0041)$ \\
\hline 1953 & $0.0379(0.0054)$ & $0.0162(0.0045)$ & $0.0983(0.0169)$ & $0.0320(0.0068)$ \\
\hline 1954 & $0.0686(0.0127)$ & $0.0192(0.0031)$ & $0.0623(0.0219)$ & $0.0139(0.0069)$ \\
\hline 1955 & $0.0577(0.0092)$ & $0.0157(0.0027)$ & $0.0531(0.0146)$ & $0.0223(0.0077)$ \\
\hline
\end{tabular}


Table A3. School mate correlations

\begin{tabular}{|l|l|l|}
\hline Birth Cohort & Unadjusted & Family adjusted \\
\hline 1959 & $0.0313(0.0063)$ & $0.0067(0.0029)$ \\
\hline 1960 & $0.0289(0.0044)$ & $0.0043(0.0034)$ \\
\hline 1961 & $0.0226(0.0035)$ & $0.0023(0.0032)$ \\
\hline 1962 & $0.0167(0.0020)$ & $-0.0000(0.0036)$ \\
\hline 1963 & $0.0126(0.0020)$ & $-0.0009(0.0038)$ \\
\hline 1964 & $0.0157(0.0015)$ & $0.0038(0.0031)$ \\
\hline 1965 & $0.0137(0.0016)$ & $0.0029(0.0029)$ \\
\hline 1966 & $0.0124(0.0015)$ & $0.0031(0.0022)$ \\
\hline 1967 & $0.0142(0.0018)$ & $0.0054(0.0024)$ \\
\hline 1968 & $0.0136(0.0017)$ & $0.0037(0.0027)$ \\
\hline 1969 & $0.0134(0.0019)$ & $0.0032(0.0033)$ \\
\hline 1970 & $0.0131(0.0018)$ & $0.0034(0.0025)$ \\
\hline
\end{tabular}

Table A4. Descriptive statistics and neighbour correlations for neighbourhoods that were matched and not matched in the pre- and post-reform analysis.

\begin{tabular}{|l|l|l|l|l|l|l|l|}
\hline Cohort & $\begin{array}{l}\text { Average } \\
\text { education } \\
\text { Matched }\end{array}$ & $\begin{array}{l}\text { Average } \\
\text { education } \\
\text { No match }\end{array}$ & $\begin{array}{l}\text { Average } \\
\text { earning } \\
\text { Matched }\end{array}$ & $\begin{array}{l}\text { Average } \\
\text { earnings } \\
\text { No match }\end{array}$ & $\begin{array}{l}\text { Neighbour } \\
\text { correlation } \\
\text { Matched }\end{array}$ & $\begin{array}{l}\text { Neighbour } \\
\text { correlation } \\
\text { No match }\end{array}$ & $\begin{array}{l}\text { Share } \\
\text { Matched } \\
\text { Pupils }\end{array}$ \\
\hline 1948 & 11.13 & 11.14 & 240133 & 249901 & .04347 & .09331 & .868 \\
\hline 1949 & 11.23 & 11.27 & 248255 & 256356 & .05873 & .09616 & .865 \\
\hline 1950 & 11.34 & 11.36 & 251938 & 262164 & .04561 & .09027 & .865 \\
\hline 1951 & 11.44 & 11.47 & 254454 & 263525 & .06010 & .08532 & .863 \\
\hline 1952 & 11.45 & 11.56 & 255013 & 270125 & .05315 & .07689 & .862 \\
\hline 1953 & 11.52 & 11.66 & 258094 & 270610 & .03496 & .07524 & .866 \\
\hline 1954 & 11.62 & 11.68 & 259919 & 269817 & .04665 & .07510 & .866 \\
\hline 1955 & 11.67 & 11.72 & 264785 & 271710 & .03620 & .05701 & .865 \\
\hline 1956 & 11.63 & 11.74 & 258100 & 268968 & .04451 & .05029 & .869 \\
\hline
\end{tabular}




\section{IZA Discussion Papers}

\begin{tabular}{|c|c|c|c|c|}
\hline No. & Author(s) & Title & Area & Date \\
\hline 939 & E. Toulemonde & $\begin{array}{l}\text { Acquisition of Skills, Education Subsidies, and } \\
\text { Agglomeration of Firms }\end{array}$ & 2 & $11 / 03$ \\
\hline 940 & $\begin{array}{l}\text { A. Constant } \\
\text { Y. Shachmurove } \\
\text { K. F. Zimmermann }\end{array}$ & $\begin{array}{l}\text { What Makes an Entrepreneur and Does It Pay? } \\
\text { Native Men, Turks, and Other Migrants in } \\
\text { Germany }\end{array}$ & 1 & $11 / 03$ \\
\hline 941 & $\begin{array}{l}\text { R. V. Burkhauser } \\
\text { J. S. Butler } \\
\text { G. Gumus }\end{array}$ & $\begin{array}{l}\text { Option Value and Dynamic Programming Model } \\
\text { Estimates of Social Security Disability Insurance } \\
\text { Application Timing }\end{array}$ & 6 & $11 / 03$ \\
\hline 942 & $\begin{array}{l}\text { R. V. Burkhauser } \\
\text { J. S. Butler } \\
\text { G. Gumus }\end{array}$ & $\begin{array}{l}\text { Dynamic Modeling of the SSDI Application } \\
\text { Timing Decision: The Importance of Policy } \\
\text { Variables }\end{array}$ & 6 & $11 / 03$ \\
\hline 943 & $\begin{array}{l}\text { J. T. Addison } \\
\text { P. Teixeira }\end{array}$ & $\begin{array}{l}\text { What Have We Learned About the Employment } \\
\text { Effects of Severance Pay? Further Iterations of } \\
\text { Lazear et al. }\end{array}$ & 3 & $11 / 03$ \\
\hline 944 & $\begin{array}{l}\text { H. Görg } \\
\text { D. Greenaway }\end{array}$ & $\begin{array}{l}\text { Much Ado About Nothing? Do Domestic Firms } \\
\text { Really Benefit from Foreign Direct Investment? }\end{array}$ & 2 & $11 / 03$ \\
\hline 945 & $\begin{array}{l}\text { R. Schöb } \\
\text { D. E. Wildasin }\end{array}$ & $\begin{array}{l}\text { Economic Integration and Labor Market } \\
\text { Institutions: Worker Mobility, Earnings Risk, and } \\
\text { Contract Structure }\end{array}$ & 2 & $12 / 03$ \\
\hline 946 & M. Leonardi & $\begin{array}{l}\text { Earnings Instability of Job Stayers and Job } \\
\text { Changers }\end{array}$ & 1 & $12 / 03$ \\
\hline 947 & U. Sunde & $\begin{array}{l}\text { Potential, Prizes and Performance: Testing } \\
\text { Tournament Theory with Professional Tennis } \\
\text { Data }\end{array}$ & 7 & $12 / 03$ \\
\hline 948 & $\begin{array}{l}\text { A. Kugler } \\
\text { G. Pica }\end{array}$ & $\begin{array}{l}\text { Effects of Employment Protection and Product } \\
\text { Market Regulations on the Italian Labor Market }\end{array}$ & 6 & $12 / 03$ \\
\hline 949 & C. J. Flinn & $\begin{array}{l}\text { Minimum Wage Effects on Labor Market } \\
\text { Outcomes under Search with Bargaining }\end{array}$ & 6 & $12 / 03$ \\
\hline 950 & $\begin{array}{l}\text { P. Garibaldi } \\
\text { E. Wasmer }\end{array}$ & $\begin{array}{l}\text { Equilibrium Employment in a Model of Imperfect } \\
\text { Labor Markets }\end{array}$ & 1 & $12 / 03$ \\
\hline 951 & $\begin{array}{l}\text { P. Garibaldi } \\
\text { E. Wasmer }\end{array}$ & $\begin{array}{l}\text { Raising Female Employment: Reflexions and } \\
\text { Policy Tools }\end{array}$ & 5 & $12 / 03$ \\
\hline 952 & $\begin{array}{l}\text { O. Raaum } \\
\text { K. G. Salvanes } \\
\text { E. Ø. Sørensen }\end{array}$ & The Neighbourhood Is Not What It Used to Be & 3 & $12 / 03$ \\
\hline 953 & $\begin{array}{l}\text { O. Raaum } \\
\text { K. G. Salvanes } \\
\text { E. Ø. Sørensen }\end{array}$ & $\begin{array}{l}\text { The Impact of a Primary School Reform on } \\
\text { Educational Stratification: A Norwegian Study of } \\
\text { Neighbour and School Mate Correlations }\end{array}$ & 5 & $12 / 03$ \\
\hline
\end{tabular}

An updated list of IZA Discussion Papers is available on the center's homepage www.iza.org. 